\title{
Assessing the Impact of Road Infrastructure on Poverty Reduction in Developing Economies: The Case of Nigeria
}

\author{
Badewa Abayomi Aderogba', Abiodun Adewale Adegboye ${ }^{2}$ (1) \\ ${ }^{1}$ Partnership for Economic Policy (PEP) in Affiliation with Université Laval, Quebec, Canada \\ ${ }^{2}$ Department of Economics, Obafemi Awolowo University, Ile-Ife, Nigeria \\ Email: badewa-abayomi.aderogba.1@ulaval.ca, aadegboye@oauife.edu.ng
}

How to cite this paper: Aderogba, B.A. and Adegboye, A.A. (2019) Assessing the Impact of Road Infrastructure on Poverty Reduction in Developing Economies: The Case of Nigeria. Modern Economy, 10, 2430-2449.

https://doi.org/10.4236/me.2019.1012153

Received: November 8, 2019

Accepted: December 28, 2019

Published: December 31, 2019

Copyright $\odot 2019$ by author(s) and Scientific Research Publishing Inc. This work is licensed under the Creative Commons Attribution International License (CC BY 4.0).

http://creativecommons.org/licenses/by/4.0/

\begin{abstract}
Infrastructure development seems appealing. However, few micro studies investigated the effect and channel of physical infrastructure on household's living standards. We addressed these issues using road infrastructure in kilometers on Nigeria's panel data. Infrastructure development measured as stress-free access to road is found to have significant direct effect on "within" households' well-being. However, the results for the isolated and non-isolated households in the entire economy and conflict-free zones are the same based on distance-quartile. In contrast, the conflict-prone zone's result is different and contrariwise. But, these outcomes suggested that not-too-distant households are better off, although from an unfamiliar viewpoint.
\end{abstract}

\section{Keywords}

Road Infrastructure, Household, Poverty, Nigeria, Panel Data Models

\section{Introduction}

The economic situation in Nigeria has been very disappointing. After decades of independence, the country is still battling with a high level of poverty. The world's poor dropped from 643.5 million to 592.7 million [1] but lamentably, around 423 million of the world's poor lived in Sub-Saharan Africa, where Nigeria has one of the largest population, in the same period. At the end of 2018, $\mathrm{Ni}$ gerians living below the threshold of US $\$ 1.25$ were 90.8 million, an appalling 46.4 percentage point of her estimated 195.6 million overall population. This socio-economic challenge seems to have stemmed from the poor condition of primary physical infrastructure, among others despite the incremental nature of 
public expenditure to GDP at current factor cost and per capita income. The Global Competitiveness Report orders Nigeria's infrastructure at the bottom is 132 out of 138 nations. Similarly, according to the executive opinion survey of the World Economic Forum [2], the inadequate supplies of infrastructure appear to be the number one restriction to trade in the country. The Federal Republic of Nigeria's Economic Recovery and Growth Plan [3] complements the information that the "substandard infrastructure" is one of the principal factors that subverts development outcomes in the past.

As far as infrastructure is concerned, we limit the definition to physical infrastructure. It encompasses transportation, energy, water and sanitation, besides information and communication technology [4]. Out of these four categories, we focus on an aspect of transportation. The forms of transportation in Nigeria are roads, railways, inland ports, pipelines for transport of natural gas, and the air transports [5]. Our center of attention is the road. Its development has been the order of the day in Nigeria perhaps, because of the general recognition that it reduces the effect of distance, hence helping to connect the national market and facilitates business which consequently reduces poverty. The justifications for this definition include among others, on the one hand, the fact that economic activities in Nigeria thrive remarkably on the use of roads.

Among all forms of transportation in Nigeria, the road sector accounts for almost 90 per cent of all internal and cross-border freight, and passenger movements [5]. The rationale behind that is the flaw in other forms of transportation, specifically the railway [6]. However, as discovered in policy paper [5], high priority has been given to the development of all the forms of transport infrastructure: to close infrastructural gaps, to accelerate economic transformation for the country, and to attain the Vision 20:20. Recently, the Chinese government also made the pledge of US\$6 billion for the funding of infrastructure in Nigeria [7]. Moreover, not long ago, Nigeria's government released the sum of 1 trillion-naira capital funds for road construction and rehabilitation among others. It is necessary for the government to invest more in infrastructure, most especially roads to explicitly pursue development with regards to inclusive growth as well as poverty mitigating policies in the whole economy [8] [9].

On the other hand is the availability of reliable and dynamic panel data which captures our definition of infrastructure at the household-level. The poor state of the road's connections and bridges are widespread. An in-depth study of the surveyed household's responses to the questionnaires reveals that they lack access to primary amenities such as roads, employment opportunities and also in participating in political activities. Hence, they are the "accessibility poor" as discovered in Seetanah et al. [10].

Many people, policymakers and studies [10], believe firmly that the poverty reduction effect of infrastructure development passes through economic growth (an indirect channel) mainly because it generates the resources to raise incomes. In the actual sense of the economy, this is disputable because not only do the few 
appropriate the generated commonwealth to themselves but also the raised incomes are not well distributed, thus leaving the masses to pine in penury.

Seetanah et al. [10] stated that the effect of economic growth on poverty reduction would be smaller or insignificant if the economic growth and the worsening distribution of income are associated. Today, Nigeria is one of the fastest growing developing countries in the world with a high poverty level, and worsening distribution of the income or wealth. That is, the distribution of income or wealth created by many, strictly shared into the pocket of the few. However, the existing pieces of literature on the poverty reduction effect of road development remains vague, particularly regarding the cause-effect channels. There are shreds of empirical evidence on why infrastructure development might be the most revolutionary not only in reducing poverty but also in tackling other development issues. Given the finite commonwealth and many development challenges, there is a need to: substantiate not only the poverty-reduction effect but also the channel to the effect; and make a wise decision on the location of infrastructure. Hence, the question is not only if the scaling-up of infrastructure, specifically "road infrastructure" mitigates poverty, but also is the valid pathway of this area of intervention to poverty reduction at the household-level. This study aims at dealing with these two distinguishable but related problems by developing an existing analytical framework, and using a rare panel data and methods to conquer part of the applied issues.

Two main research issues are noticeable. On the one hand, is the strain in obtaining reliable proxies for roads. There are three proxies for infrastructure availability which are the local road quality/density, the travel distance to the destination, and the travel time to destination. However, the availability of infrastructure does not translate to its accessibility [11] [12]. Hence, in this study, we used the second measure based on Pouliquen's work [13] that the ability of the poor to access available infrastructure facilities services is a crucial issue. The distance to the nearest main roads depicts destinations in this study because it is self-evident that many productive and economic activities happen on the major road's sides. Besides, the major roads lead to various workplaces be it on the farm or off-farm. Therefore, if the access to road is inadequate, then poorer households in less-developed communities cannot benefit from economic activities and services such as school and health centers [14]. The access rates to infrastructure affect not only marginalization and inequalities but also poverty.

On the other hand, is the problem of conquering the promising source of endogeneity emanating from the non-random placement of roads. Innumerable studies not only at the macro-level but also micro-level which investigated the effect of infrastructure on poverty did not tackle the endogeneity problem of attributing infrastructure to a particular area. Nonetheless, Gachassin, Najman, \& Raballand [15]; Khandker, Bakht, \& Koolwal [16]; and Walle \& Mu [17] tackled the endogeneity challenge of road placements in their studies. Whenever there is endogeneity, the estimates will no longer be unbiased. Being conscious of the 
remark, we take advantage of the panel structure of our data set that traced the same households between 2010-2013, besides an empirical model based on multivariate regression framework to tackle the issue. The infrastructural modules of the datasets remain unused in existing literature.

The results indicate that poverty alleviated directly for households with reduced road access in kilometers. Besides, increased road access in the rural areas also led to higher poverty reduction in the urban areas. We also found that not-too-distant households to the major roads in conflict and less violent conflict areas contribute more to within household's per capita consumptions.

The synopsis of this paper proceeds as follows: The second part develops the analytical framework and also the relevant empirical evidence. The third part unfolds the data issue and methodology. The fourth part presents the results, empirical findings, and the discussion. Finally, the fifth part offers the policy recommendations.

\section{Analytical Framework and Empirical Evidence}

\subsection{Analytical Framework}

We followed the Ali \& Pernia's framework [18] in which the channel through which road infrastructure leads to poverty reduction could be either director indirect. On the one hand, if the determinants operate through the employment that gives wages to the poor, then the pathway to poverty reduction is a direct (income) effect. In addition, if the determinants operate through economic growth which influences the supply and prices of primary goods to the poor, then the pathway to poverty alleviation is an indirect (growth) effect. We focused on the direct channel because other channels are less controlled by the poor but more by the few who pocket the contribution of infrastructure to economic growth, thus diverting the gains intended for the poor.

To achieve our aims, we construed the definition of poverty as the one connected to household's real consumption per capita following Ali \& Pernia [18]. Hence, the direct effect of infrastructure on poverty outcomes will be contingent on the changes in the enumerated determinants. Road infrastructure can help to alleviate costs in term of shorter transiting distance in kilometers spent by households. A pertinent instantaneous effect of road infrastructure development is job creation, economic diversification, and more income as presented in Ali \& Pernia [18], Gachassin et al. [15], and Howe [19], which directly augments households' real consumptions per capita, hence better economic well-being. By assumption, households' access to major roads increases the economic worth of agricultural and non-agricultural employments or outputs, generating high households' wages, hence poverty reduction.

\subsection{Empirical Evidence}

Several studies have investigated the connection between road infrastructure and poverty reduction. However, evidence in developing economies including Nige- 
ria is scarce, more importantly at the household-level. Based on the aggregate macro-level data from Nigeria between 1970:1 and 2005:4, a negative indirect (economic growth channel) link was established between investment in infrastructure and poverty. However, investment in social infrastructure compared to physical infrastructure proved to have a greater poverty-reduction effect [20]. Runsinarith [21] considered government investments in irrigation, road, electricity and mobile phone in two provinces in Cambodia and found that the infrastructure variables directly reduced poverty incidence. In Tanzania, using micro data, Fan, Nyange, \& Rao [22] assessed the poverty-reduction effect of public investment and concluded that access to road network and other public services such as electricity has a valuable effect on the household's income.

Khandker, Bakht, \& Koolwal [16] also established the effect of road investments on rural household's poverty and other opportunities between 1997 and 2001 in Bangladesh. Using the difference-in-difference method linked to the household-level fixed effect, they showed that investment on rural roads directly reduced multi-dimensional poverty. Similarly, study by Dercon, Gilligan, Hoddinott, \& Woldehanna [23] on 15 Ethiopian villages showed that the access to the all-weather roads mitigated poverty by 6.9 percentage points and increased consumption by 16.3 percentage point. Moreover, another work on 20 developing countries revealed different confusing pathways to urban absolute poverty reduction through infrastructure. However, the direct channel proxy with length of paved roads appears statistically significant from a macroeconomics perspective [10]. Lately, Ali et al. [11] [12] study on road transport infrastructure and welfare in Nigeria showed that lessening the transport costs would yield significant multi-dimensional gains through the source of income and location on the one hand. It also decreased the likelihood of being multi-dimensionally poor.

This study has a connection with the existing pieces of literature and the ongoing discourse on the link between the poverty-reduction effect of road infrastructure. From our view, one of the reasons for this discourse is because of the inconclusiveness regarding cause-effect evidence. Moreover, the indirect (economic growth) channel of the proposed analytical model has in the actual sense not translated into poverty reduction.

\section{Data and Methodology}

\subsection{Data}

The dataset used in this study emanates from the World Bank Microdata Library. It is a dataset of 5000-panel households. The survey was carried out by the Nigeria's National Bureau of Statistics (NBS) based on the World Bank's Living Standard Measurement Survey methodology. The year of study is between 2010 and 2013, the year for which datasets were available. The NGHS panel is nationally and regionally representative randomly selected sub-sample of panel households from NGHS cross-sections households. The attrition rate is $24 \%$. The dataset encompasses detailed information on three modules of questionnaires 
which provides a piece of comprehensive and versatile survey information. It offers detail information on household's farming and non-farming economic and income generating activities operating in different sectors, demographic conditions, asset ownership, other income sources, food, and non-food expenditure consumption, access to infrastructures such as the major roads, the school, and the health center etc., besides the socio-economic and well-being proxies.

The panel survey is biennial by design and was conducted using the two-stage probability methodology. The panel households were visited twice per wave: the two visits conform to the post-planting (August to November) and post-harvest (February to April) periods. Nationally, there were 500 primary sampling units, each having 10 households. To attain the goal of this study, we processed and rescaled the original aggregate consumptions' datasets with some variables for a comprehensive analysis using STATA. With regards to these activities, we have 4699 and 4536 observations for waves one and two datasets respectively. Therefore, we finally have 9235-panel observed households combined, 1128 of whom were not interviewed in both waves. In short, we used 8107 panel-observed interviewed households from both waves.

\subsection{Choice of Variables}

Household's welfare indicators were construed using log of nominal consumption per capita as used in Gachassin et al. [15], Runsinarith [21], and also poverty status dummy as used in Fan, Nyange, Rao, \& others [22]. Following this method, we were able to keep both the continuous and discrete dependent variables aspoverty measures. We proxied the access to the road by the household's distance to the nearest major roads in kilometers. We also controlled for the direct pathway variables: employment and wage. Household's employment is a dummy variable on whether households are working, be it in agriculture or non-agriculture sectors, or not, and each household wage is proxied by households' savings, a dummy measure of households with another source of income or not. Household's characteristics which are the household's head level of education, marital status, gender, and age, the household size and, the households' location dummy, etc. were also included as controls.

The household's living standard measures, could be proxied by many indicators such as the per capita income and consumption, the inequality and the FGT poverty measures etc. However, household's consumption per capita seems more accurate in the existing literature in developing countries. Therefore, we used it as number one measure of poverty in this study. Following from Carlos, Cantó, Del Río, \& Sarabia's study [24], consumption per capita is less explosive compared to incomes. Likewise, its use lessens the likelihood of classifying households wrongly into poor and non-poor status. Furthermore, during the survey periods, the probability of underreporting consumption is smaller when compared to the income figures. Lastly, this measure reflects long-run wellbeing. Indeed, it illustrates household's potential to meet their essential needs and also 
their access to another source of income like savings when income is low.

The second measure is the household's poverty status, either poor or non-poor. We classify households to the poor and non-poor groups by deducting the revised national absolute poverty line for each wave $(51,482.14$ naira for wave 1 and 63,205.8 naira for wave 2) from each household's consumption per capita. Thanks to the Living Standards Measurement Study-Integrated Surveys on Agriculture by the World Bank for making the poverty lines available. The derivation of these poverty lines involves the aggregation of the food and non-food basic needs. We apply both lines because they have national recognition. Thus, any household whose consumption per capita is under the stated poverty lines is poor, but non-poor if otherwise.

The NGHS questionnaire has a section where distances from households' residence to major road were recorded. In this study, one of the main variables of interest is the road infrastructure proxy with the distances in kilometers to the major roads. Besides are the channel of influence variables, that is the household's labor supply and other source of income dummies. Finally, the control variables encompass the household's characteristics.

\subsection{Methodology}

The choice of variables is not only based on the Proofs from the existing literature but also on the availability of a self-evident analytical framework that traces the links. As a result, we evaluated and reported a multivariate regression model that combined different panel data models. This study investigates the analytical framework on the link between infrastructure development and poverty reduction within the Nigerian households. The yardstick model is the Kongens [25] log-log pooled linear regression model. We pooled the two waves to make the presentation easier and also to accommodate more information. Below is the pooled regression model for this study:

$$
Y_{i t}=X_{i t} \cdot \beta+Z_{i t} \cdot \gamma+\varepsilon_{i t}
$$

$Y_{i t} \Rightarrow$ The household's consumption per capita for household $i$ at time $t$. A continuous dependent variable in logarithm to normalize, and aid the analysis of the coefficients in terms of elasticities as we have seen in [21] [26].

$X_{i t} \Rightarrow$ An array that encloses the variables of interest that is road infrastructure.

$Z_{i t} \Rightarrow$ An array that encloses the control variables.

$\beta$ and $\gamma$ are estimated parameters, and $\varepsilon_{i t}$ is the error term presumed to retain the standard properties. We estimated the model using OLS when $Y_{i t} \Rightarrow$ households' consumptions per capita.

The design of the regression analysis for this study is not only guided by the analytical model but also an iterative operation of trial and error to identify the model that best fits the study data sets.

The starting point model is limited because if there are unobserved factors that affect the response and the explanatory variables, then the results are biased. 
More limitations of this method are present in Johnston [27] and Kennedy [28] textbooks. However, the promise of the panel structure and the time order of the data set is to lessen these challenges because it helps to control the time-invariant effect, and also the unobserved heterogeneity. It is likely that the unobserved factors $\left(\alpha_{\mathrm{I}}\right)$ correlate with the independent variables hence we estimated the fixed effects specification validated by the Hausmann test which disregards the random effect model $(\mathrm{P}<0.0001)$. Therefore, the conventional fixed-effect specification has the following structure:

$$
Y_{i t}=X_{i t} \cdot \beta+Z_{i t} \cdot \gamma+\alpha_{i}+\eta_{i t}
$$

$\alpha_{\mathrm{I}} \Rightarrow$ individual-household, time-invariant well-being outcomes, and $\eta_{i t} \Rightarrow$ the error terms following from Johnston [27]. The specification examines mainly the well-being changes for each household over time, the termed within transformation. However, it has its demerit because all time-invariant variables collapse into the error term [29].

The conditional logit fixed effect specification aims at the variation in observed data within households across time [30]. In this specification, we used households interviewed at least twice. The method is contingent on two conditions. On one hand, the response variable must be proxied by at least two occasions of each household. Besides, a higher amount of household's explanatory variables must not be time-constant. Our poverty lines as demonstrated in Fan et al. [22] study was used to create dummy discrete poverty measure which indicates that households' poverty status changes over time. The poverty status dummy variable depicts a non-poor household by 1 and a poor household by 0 . Hence, households are construed to be poor if their consumption per capita are below the poverty line and non-poor if otherwise. We applied this measure due to the availability of panel household's data which are comparable over time, besides the latest revised poverty lines by LSMS. No matter how one looks at the specification marginal effect estimate, it cannot be explained because it eliminates the confidence interval of the individual effect. Hence, we used the STATA command aextlogit by Kemp \& Silva [31] on the specification to report the approximate semi-elasticities which are easier to interpret. We estimated the conditional fixed-effects model without applying the logarithm form because of the specification conditions.

According to Van de Walle [32], there are various correlated factors besides the placement of better road infrastructure that determines higher well-being or poverty outcomes. A failure to tackle the empirical issue of infrastructure placement not being random, for example, the omitted variables challenge, among others as explained in Gachassin et al. [15] implies dealing just with correlation but not causality. For instance, geographical factors among other determinants can be responsible for the development of better roads and hence enhanced well-being. There are different statistical specifications to deal with endogeneity issues. However, each has its drawbacks and potentials, and it is not possible to eliminate all endogeneity issues such as the reverse causality and others at this 
stage due to our ideal data set material. Regardless of the exact evaluation strategy, however, our multivariate regression specification potentially reduced the challenge to a reasonable extent by controlling for everything specific about the households.

\section{Empirical Findings and Discussions}

\subsection{Relationship between Variables}

Although the datasets used in the study are publicly available for the period between 2010 and 2016, we considered the periods for which we have a reliable panel structure of the datasets. Besides, the study concern road infrastructure which development has been sluggish and slow over the year. Although, in the last 15 years, subsequent governments have been making efforts on its provisions could do within the economy, however, issues remain intact. Urban congestion and poverty are very high, resulting from the uneven development of road between the rural and urban areas, with a high concentration on the latter. On the other hand, the neglect of the rural areas may also have worsened their productivity and livelihood. About $70 \%$ of Nigerians live in rural areas. The rural dwellers face challenges in the form of difficult access to facilities and amenities to enhance their income and living standard, besides worsened poverty situation. Hence, the question is whether road infrastructure contributes to poverty reduction, if yes, through which channels?

Table 1 and Table 2 present the relationships between the dependent and explanatory variables. The vectors of the explanatory variables are the same, but different arrays of control variables. The statistical significance is at $5 \%$ critical level after been pooled. The reduction in distance of each household to the major road lessens the likelihood of being poor by $9 \%$ as each households' consumption

Table 1. Per capita consumption correlation with the explanatory variables.

\begin{tabular}{|c|c|c|c|c|c|c|c|c|c|c|}
\hline Variable & $\begin{array}{c}\text { Consumption } \\
\text { Per Capita }\end{array}$ & Road & age & Labor & savings & Sex & $\begin{array}{l}\text { Marital } \\
\text { Status }\end{array}$ & Location & Education & $\begin{array}{l}\text { Households } \\
\text { Size }\end{array}$ \\
\hline $\begin{array}{l}\text { Consumption } \\
\text { per capita }\end{array}$ & 1 & & & & & & & & & \\
\hline Road & $-0.1183^{\star}$ & 1 & & & & & & & & \\
\hline Age & $-0.1042^{\star}$ & $-0.0533^{\star}$ & 1 & & & & & & & \\
\hline Labor & $0.1596^{*}$ & 0.0006 & $-0.0370^{*}$ & 1 & & & & & & \\
\hline Savings & $0.0723^{*}$ & -0.0358 & -0.0095 & $-0.0212^{*}$ & 1 & & & & & \\
\hline Sex & $-0.0662^{\star}$ & $0.0688^{*}$ & $-0.1635^{\star}$ & $-0.0877^{\star}$ & $0.0333^{*}$ & 1 & & & & \\
\hline marital status & $-0.1905^{\star}$ & $0.0847^{*}$ & $-0.0721^{\star}$ & $-0.2205^{\star}$ & $0.0343^{*}$ & $0.6923^{*}$ & 1 & & & \\
\hline Location & $0.2812^{\star}$ & $-0.2618^{\star}$ & $-0.0510^{*}$ & -0.0145 & $0.0612^{*}$ & $-0.0603^{\star}$ & $-0.0811^{\star}$ & 1 & & \\
\hline Education & $0.1374^{\star}$ & 0.0159 & 0.0166 & $-0.0910^{*}$ & $0.0668^{*}$ & $0.1077^{\star}$ & $0.1089^{*}$ & $0.0868^{*}$ & 1 & \\
\hline $\begin{array}{l}\text { Households } \\
\text { size }\end{array}$ & $-0.3116^{\star}$ & $0.0214^{*}$ & $0.0787^{*}$ & $-0.3384^{\star}$ & 0.0106 & $0.2703^{*}$ & $0.3902^{*}$ & $-0.1249^{*}$ & $0.1521^{*}$ & 1 \\
\hline
\end{tabular}

*Indicate critical level of 5\%. Source: Author's computation from Nigeria general households survey LSMS 2010-2013. 
Table 2. Poverty status dummy correlation with the explanatory variables.

\begin{tabular}{cccccc}
\hline variable & Povertystatus & Road & age & Labor & Savings \\
\hline Poverty status & 1 & & & & \\
road & $0.0863^{*}$ & 1 & & & \\
age & $0.0561^{*}$ & $-0.0533^{*}$ & 1 & & \\
Labor & $-0.0869^{*}$ & $0.0006^{\star}$ & $-0.0370^{*}$ & 1 & \\
savings & $-0.0565^{*}$ & $-0.0358^{*}$ & -0.0095 & $-0.0212^{*}$ & 1 \\
\hline
\end{tabular}

${ }^{*}$ Indicate critical level of 5\%. Source: Author's computation from Nigeria general households survey LSMS 2010-2013.

per capita increases by $11 \%$. Combining the two poverty measures, the correlations suggest that not-too-distant and employed households' members are expected to gain from the use of our definition of infrastructure. Other control variables also offer the expected trend of relationships.

The average distance to the major roads for households in the urban areas is $4.84 \mathrm{~km}$ and $2.32 \mathrm{~km}$ in 2010 and 2013 respectively. On the other hand, it is 17.3 $\mathrm{km}$ and $7.75 \mathrm{~km}$ in 2010 and 2013 respectively for households in rural areas. In the urban areas, there is a significant fall from $4.8 \mathrm{~km}$ to $2.3 \mathrm{~km}$ between 2010 and 2013 in the average distance of the non-poor households to the major roads. In this same area and between the same period, there is also a significant fall from $6.3 \mathrm{~km}$ to $2.5 \mathrm{~km}$ in the poor household's distance on the average to the major roads.

There is as well a significant fall in the rural non-poor households' distance on the average to the major roads from $16.2 \mathrm{~km}$ to $7.4 \mathrm{~km}$ between 2010 and 2013 . Similarly, in the rural areas, there is a significant fall in the poor household's average distance to the major roads from $21 \mathrm{~km}$ and $8.27 \mathrm{~km}$ between 2010 and 2013. However, the non-poor and not the poor households in both rural and urban areas are indeed closer to the major roads on the average. The household's average distance to the major roads in the urban areas shows that they are not isolated. However, for the rural households, it shows that they are isolated. Indeed, the far-reaching margin between non-poor and poor households' average distance to the major roads in 2010 became very narrow in 2013 in both areas. Finally, the households size variable shows that those with little members contribute more to consumptions, and households with a large number of individuals are expected to be the poor.

The correlation matrix, as shown in Table 2, confirms the co-movement of the measures of the channels (the savings and employment status of each household's members) between infrastructure and poverty reduction. Household's members with occupation are expected to contribute more to households' consumption per capita, and those without employment are anticipated to be poor. Households with savings are anticipated to contribute more to per capita consumption while those without savings are likely poor. An interesting descriptive analysis is on the comparison of the average distance to the major road in 
kilometers between the household's occupational status, and saving's dummy over the years. Summarily, households with working-class members who are not-too-distant to the road are expected to contribute more to consumption per capita. Indeed, they are anticipated to be non-poor. However, not only excluded households with jobless members are expected to be poor but also the ones with working-class members based on the measures of well-being in this study.

\subsubsection{Household's Consumption Effect of Infrastructure Development}

The results of the pooled regression and the unconditional fixed-effects estimations are under Table 3. The results of the conditional logit fixed model are also under Table 4. The analysis of the result in Table 3 and Table 4 are in term of elasticities and approximate semi-elasticities respectively. The benchmark analysis is the pooled regression estimation results. It revealed that all the explanatory variables except the marital status and labor supply coefficient values proved to be statistically significant at $1 \%$ or $10 \%$ with the anticipated signs. The limitations of this approach are self-evident as revealed in the third section of this study. Therefore, the estimations from the panel data methods.

From the result of fixed-effect, the household's characteristics and the channel of influence variables are statistically significant and also have the expected signs. Among the observed factors, the household size has the greater effect on each household per capita consumption. It is statistically significant at $1 \%$, and the sign is negative. We noted that irrespective of each household's consumption per capita, a $10 \%$ fall in each household's size increased the per capita consumption by almost $47 \%$. It is consistent with the arguments in the existing literature that the household's size is an important determinant of household's consumption per capita. The lesser the household size, the higher the consumption per capita, and vice-versa.

As expected the household's head marital status has a negative association with the household's consumption per capita. The fact that marital status is an important determinant of household's size which in turn significantly affects the ability of a household to enjoy higher well-being can be used to explain that. Thus, we noted that the household's marital status "not married" implies higher household's consumption per capita. The sign of the household's head gender took another direction with the household's consumption per capita. Our results show that the female-headed households contributed more to the household's consumption per capita than their male counterpart. However, the marital status

Table 3. Household's mean distance to the road with respect to the area of location.

\begin{tabular}{ccc}
\hline Area of location & Year & Average distance in Kilometers \\
\hline \multirow{2}{*}{ urban } & 2010 & 4.84 \\
& 2013 & 2.32 \\
\multirow{2}{*}{ Rural } & 2010 & 17.3 \\
& 2013 & 7.75 \\
\hline
\end{tabular}


Table 4. Pooled and fixed-effect results for households' per capita consumption.

\begin{tabular}{|c|c|c|c|c|}
\hline & $(1)$ & $(2)$ & $(3)^{1}$ & $(4)$ \\
\hline & Pooled regression & Fixed & Fixed effect for & Fixed effect for \\
\hline & & Effect & $\begin{array}{c}1^{\text {st }} \text { quartile (less than } \\
0.86 \mathrm{~km})\end{array}$ & $\begin{array}{c}4^{\text {th }} \text { quartile (beyond } \\
14.23 \mathrm{~km} \text { ) }\end{array}$ \\
\hline \multicolumn{5}{|c|}{$\log$ of consumption per capita } \\
\hline \multirow[t]{2}{*}{$\log$ of distance to the road } & $-0.034^{\star * *}$ & $-0.011^{\star * *}$ & $-0.016^{\star}$ & 0.005 \\
\hline & $(0.008)$ & $(0.003)$ & $(0.009)$ & $(0.017)$ \\
\hline \multirow[t]{2}{*}{ log of household head age } & $-0.0585^{*}$ & $0.068^{*}$ & 0.031 & 0.102 \\
\hline & $(0.035)$ & $(0.039)$ & $(0.066)$ & $(0.069)$ \\
\hline \multirow[t]{2}{*}{ households' member labor supply dummy } & -0.005 & $0.041^{* * *}$ & $0.053^{* *}$ & 0.019 \\
\hline & $(0.023)$ & $(0.015)$ & $(0.025)$ & $(0.026)$ \\
\hline \multirow[t]{2}{*}{ households' other source of income dummy } & $0.285^{\star * *}$ & $0.072^{* *}$ & $0.111^{* *}$ & 0.084 \\
\hline & $(0.045)$ & $(0.035)$ & $(0.053)$ & $(0.073)$ \\
\hline \multirow[t]{2}{*}{ households' head sex dummy } & $0.102^{* * *}$ & 0.051 & 0.000 & 0.014 \\
\hline & $(0.038)$ & $(0.068)$ & $(0.109)$ & $(0.102)$ \\
\hline \multirow[t]{2}{*}{ households' heads marital status } & 0.001 & -0.043 & -0.001 & $-0.101^{\star *}$ \\
\hline & $(0.032)$ & $(0.026)$ & $(0.050)$ & $(0.047)$ \\
\hline \multirow[t]{2}{*}{ households' area of residence } & $0.337^{\star * *}$ & $-0.293^{* * *}$ & -0.296 & \\
\hline & $(0.035)$ & $(0.113)$ & $(0.180)$ & \\
\hline \multirow[t]{2}{*}{$\log$ of households' head level of education } & $0.317^{* * *}$ & $0.062^{* * *}$ & $0.109^{* * *}$ & $0.039^{*}$ \\
\hline & $(0.035)$ & $(0.015)$ & $(0.031)$ & $(0.021)$ \\
\hline \multirow[t]{2}{*}{$\log$ of households' size } & $-0.529^{* * *}$ & $-0.467^{\star * *}$ & $-0.488^{* * *}$ & $-0.371^{\star * *}$ \\
\hline & $(0.019)$ & $(0.017)$ & $(0.026)$ & $(0.029)$ \\
\hline \multirow[t]{2}{*}{ Constant } & $11.28^{* * *}$ & $11.77^{* * *}$ & $12.01^{* * *}$ & $11.33^{* * *}$ \\
\hline & $(0.164)$ & $(0.168)$ & $(0.297)$ & $(0.276)$ \\
\hline Observations & 6990 & 6990 & 2680 & 2396 \\
\hline R-squared & 0.404 & 0.226 & 0.239 & 0.161 \\
\hline Number of HHID & & 3495 & 1340 & 1198 \\
\hline Household FE & & YES & YES & YES \\
\hline
\end{tabular}

Robust Standard errors in Parenthesis ${ }^{* *},{ }^{* *},{ }^{*}$ indicate significance level at $1 \%, 5 \%$, and $10 \%$ respectively.

and the gender of the household's head are not statistically significant. It is self-evident because both variables are time-invariant. The household's head age is statistically significant at $10 \%$ and the sign is positive. The elasticity of the household's consumption per capita to the age of the household's head age is 0.07 meaning that when the age of the household's head increases by a year, the consumption per capita increased by $7 \%$. The level of education of the household's heads is statistically significant at $1 \%$. As shown in Table 3 , the elasticity of the household's consumption per capita to the household's head level of education is 0.06 indicating that when the household's level of education increases by $1 \%$, consumption per capita increased by $6 \%$. This shows the fact that educa- 
tion is an essential determinant of labor output which is an important area of influence that significantly affects the poor household's ability to contribute more to consumption per capita from their wages and savings through enhanced road.

The direct passage of effect variables that is labor force and savings as exemplified in our analytical framework are also statistically significant. They both positively contributed toward higher household's consumption per capita. The labor force variable for each household shows that a $10 \%$ increase in each household's labor force raises each household's consumption per capita by $4 \%$, hence poverty reduction. Besides, the degree of responsiveness of the within household's consumption per capita to each household savings is $7 \%$. It means that when each household savings increases by $1 \%$, consumption per capita increased by $7 \%$. Afterwards it is the household's area of residence. The coefficient value for rural-urban dummy is negative and statistically significant at $1 \%$. It shows that irrespective of household's consumption per capita, a 10\% likelihood of movement from the urban to the rural areas, lead to a $30 \%$ increase in each household's consumption per capita in the urban areas. It indicates that poverty is an urban phenomenon as the results indicate that migration from urban to rural areas lessen within household's poverty. It is in line with Ogun [20] which revealed that poverty site of concentration is the urban area.

There exists a statistical significance but negative effects which is found to be consistent with the arguments that a stress-free distance to the major roads has a significant poverty-reduction effect. The results show that a $10 \%$ decrease in households' distance to the major roads in kilometers raised their consumption per capita by $1 \%$, implying a household with a better proximity in term of access to major roads has a higher consumption per capita, hence less poverty burden. The Fan et al. [22]; Gachassin et al. [15] \& Runsinarith [21] studies have earlier established similar position.

For further reliable evidence, we partitioned the variables of interest into quartiles (less than $4.82 \mathrm{~km}$ and beyond $14.82 \mathrm{~km}$ ). The fixed effect results in column 3 and 4 of the result indicates the multiplicative effect of the access to the major road, the household's savings and size, labor supply and household's head level of education on per capita consumption. It shows that each household with positive part of the stated variables contribute significantly to household's per capita consumption. The results show that proximity to the major roads is indispensable for each household consumption per capita consequence of the irrelevancy of the direct pathway variables for the too-distant households. It is consistent with the analytical framework that households' easy access to the major roads has an indisputable direct households' poverty reduction effect.

\subsubsection{Households' Poverty Status Effect of Infrastructure Development}

Table 4 presents the semi-elasticities estimates using some covariates with the poverty status of the households from the conditional fixed effect approach. The odds ratio coefficients from the method cannot offer the marginal effects because they ignore the confidence interval. Besides, they are also misleading and 
not that easy to analyze. From the results, 921 groups sometimes during the study periods escaped poverty. A year increase in the age of household's head statistically raised the non-poor household's numbers by almost $2 \%$ on the average at $1 \%$ level of significance.

The semi-elasticity of the household's poverty status to road's development is negative 0.04 at $1 \%$ level of significance. It shows that when the household's distance to the major roads reduces by $1 \%$, the household's poverty status "the poor" reduced by $40 \%$ on the average. Furthermore, the semi-elasticity of each household poverty status to a household labor supply status is negative of about 0.30 at $5 \%$ level of significance indicating that when the labor supply status "the employed" within a household increases by $1 \%$, the poor reduced by almost $30 \%$ on the average. The same interpretation goes for household's saving status "with savings". The average elasticity of household's poverty status to the savings status "with savings" is negative and about 0.9. It means that when the households with savings increases by $1 \%$, the poor reduced by almost $87 \%$ on the average at $5 \%$ level of significance. The poor households seized the opportunities of an enhanced road and get involved in economic activities which raised their well-being. This poverty-reduction effect from road development was substantiated through the direct pathway.

\subsubsection{Infrastructure and Household's Consumptionin Conflict-Prone and Conflict-Free Zones}

To further examine the effect of infrastructure development on household's consumption per capita, we partitioned the data set according to conflict-prone zone (North East) and conflict-free zone (other 5 zones together) within Nigeria. In Nigeria, there are six geopolitical zones. Following the historical path, one out of all is a conflict-prone zone. It is a unique geopolitical class frequently affected by Boko-Haram insurgencies, an armed conflict which led to the death of many people and the deliberate destruction of infrastructure. Boko-Haram insurgencies became an issue of concern in Nigeria from the beginning of periods under consideration for this study. Based on the partition, we examined the effect of road development on the continuous dependent variable.

Table 5 presents the estimates of the fixed effect approach for the conflict-prone zone. The distance to the major roads for the not-too-distant and the too-distant households is statistically significant at $5 \%$. In the conflict-prone zone, the elasticity of the household's consumption per capita to the distance to the major roads for not-too-distant and too-distant households are 0.36 and negative 0.39 respectively. The elasticities indicate that when the distance to the major roads increases by $10 \%$, the household's consumption per capita increased by $36 \%$ for the latter, and reduced by $39 \%$ for the former. It means that living too close or too far to the major roads in a less secure area is detrimental to household's consumption per capita. Hence, from the road development perspective in the conflict-prone area, near-exclusion is beneficial, but isolation is also harmful to the household's well-being. Although, the results contradict 
Table 5. Conditional fixed effect results for households' poverty status.

\begin{tabular}{ccc}
\hline & $(1)$ & $(2)$ \\
\cline { 2 - 3 } & Conditional fixed Effect & $\begin{array}{c}\text { Approximate } \\
\text { semi-elasticity }\end{array}$ \\
\hline Poverty Status (poor $=0$ and & non-poor $=1)$ & \\
\hline log of the distance to the road & $-0.056^{* * *}$ & $-0.042^{* * *}$ \\
log of the household's head age & $(0.006)$ & $(0.004)$ \\
household's member labor supply dummy & $0.024^{* * *}$ & $0.018^{* * *}$ \\
households' other source of income dummy & $(0.007)$ & $(0.005)$ \\
& $-0.401^{* *}$ & $-0.299^{* *}$ \\
Observations & $(0.160)$ & $-0.119)$ \\
Number of HHID & $-1.165^{* *}$ & $(0.384)$ \\
Household FE & $(0.515)$ & 1842 \\
& 1842 & 921 \\
\hline
\end{tabular}

Standard errors in parentheses. ${ }^{* *},{ }^{*}$, and ${ }^{\star}$ indicate significance level at $1 \%, 5 \%$ and $10 \%$ level of significance respectively.

the usual isolation problem in the existing literature. Nonetheless, they have the same interpretation as not-too-distant households from the road are better off in all situations.

The level of education of the household's head as anticipated has a positive association with higher consumption per capita for the too-distant and not-too-distant households in the conflict-prone area. However, the level of education estimates for the household's heads is not statistically significant. It supports one of the main reasons for armed conflict in the area, that is prohibited western education. Hence, whether the household's head goes to school or not in the conflict-prone area implies nothing for household's consumption per capita.

Table 6 and Table 7 present the results for the fixed effect model estimated for the conflict-free zones and the entire economy. The results indicate that living very close to the road in conflict-free zones has a significant effect on the within households' per capita consumption. The elasticity indicates that when the distance to the major roads decreases by $10 \%$, the household's consumption per capita increased by $5 \%$. It is statistically significant at $5 \%$. It means that living very close to the road in a more secure area is beneficial to households' consumption per capita. Besides, the results indicate that the reduction in the distance to the major roads in conflict-free zones for the excluded households has a strong positive impact on households' consumption per capita. It shows that a $10 \%$ decrease in the distance to the major roads in conflict-free zones reduced each excluded household consumption per capita by $16 \%$ at a $5 \%$ level of significance. 
Table 6. Fixed-effect estimate for households' per capita consumption for conflict-prone zone.

\begin{tabular}{|c|c|c|}
\hline & (1) & $(2)$ \\
\hline & $\begin{array}{l}\text { Fixed effect (less than } \\
0.86 \mathrm{~km})\end{array}$ & $\begin{array}{c}\text { Fixed effect (beyond } \\
14.23 \mathrm{~km})\end{array}$ \\
\hline \multicolumn{3}{|l|}{ log of per capita consumption } \\
\hline \multirow[t]{2}{*}{$\log$ distance to the road } & $0.360^{\star *}$ & $-0.391^{\star *}$ \\
\hline & $(0.138)$ & $(0.181)$ \\
\hline \multirow[t]{2}{*}{ log of household head age } & -0.201 & -0.187 \\
\hline & $(0.521)$ & $(0.242)$ \\
\hline \multirow{2}{*}{$\begin{array}{l}\text { household's member labor } \\
\text { supply dummy }\end{array}$} & 0.207 & 0.055 \\
\hline & $(0.135)$ & $(0.067)$ \\
\hline \multirow[t]{2}{*}{$\begin{array}{l}\text { household's other source of } \\
\text { income dummy }\end{array}$} & - & $0.280^{*}$ \\
\hline & & $(0.144)$ \\
\hline households' head sex dummy & - & - \\
\hline \multirow[t]{2}{*}{ household's heads marital status } & $-0.420^{*}$ & $-0.330^{*}$ \\
\hline & $(0.209)$ & $(0.170)$ \\
\hline $\begin{array}{l}\text { household's area of residence } \\
\text { (rural or urban) }\end{array}$ & - & - \\
\hline \multirow[t]{2}{*}{$\begin{array}{l}\text { log of household's head level } \\
\text { of education }\end{array}$} & 0.058 & 0.095 \\
\hline & $(0.091)$ & $(0.071)$ \\
\hline \multirow[t]{2}{*}{$\log$ of households' size } & $-0.752^{\star * *}$ & -0.085 \\
\hline & $(0.155)$ & $(0.085)$ \\
\hline \multirow[t]{2}{*}{ Constant } & $14.03^{* * *}$ & $13.24^{* * *}$ \\
\hline & $(1.79)$ & $(1.121)$ \\
\hline Observations & 78 & 208 \\
\hline R-squared & 0.713 & 0.139 \\
\hline Number of HHID & 39 & 104 \\
\hline Household FE & YES & YES \\
\hline
\end{tabular}

Robust standard errors in parentheses. ${ }^{* *},{ }^{* *}$, and ${ }^{*}$ indicate significance level at $1 \%, 5 \%$ and $10 \%$ respectively.

\section{Conclusions and Policy Recommendations}

Infrastructure investment has become a common route out of the development challenges that many developing countries face. It may be appealing theoretically from a policy point of view. However, in SSA, a few micro-studies have empirically explored the analytical framework that links road infrastructure and poverty reduction. Our study filled these gaps in literature by empirically validating the direct poverty reduction effect of road infrastructure development using rare panel data with the records of variables never used in any existing studies. Not 
Table 7. Households consumption for whole and conflict-free zones.

\begin{tabular}{|c|c|c|}
\hline 1 & $\begin{array}{c}\text { Fixed effect } \\
\text { (Less than } 0.86 \mathrm{~km} \text { ) }\end{array}$ & $\begin{array}{c}\text { Fixed effect (beyond } \\
14.23 \text { ) }\end{array}$ \\
\hline \multicolumn{3}{|c|}{ log of per capita consumption } \\
\hline \multirow[t]{2}{*}{$\log$ of the distance to the road } & $-0.055^{\star \star}$ & $-0.161^{\star *}$ \\
\hline & $(0.023)$ & $(0.0737)$ \\
\hline \multirow[t]{2}{*}{ log of the household's head age } & -0.016 & $0.224^{*}$ \\
\hline & $(0.131)$ & $(0.132)$ \\
\hline \multirow[t]{2}{*}{ households' member labor supply dummy } & 0.015 & 0.010 \\
\hline & $(0.037)$ & $(0.055)$ \\
\hline \multirow[t]{2}{*}{ households' other source of income dummy } & $0.177^{*}$ & $0.311^{\star *}$ \\
\hline & $(0.103)$ & $(0.138)$ \\
\hline \multirow[t]{2}{*}{ households' head sex dummy } & 0.173 & $-0.296^{\star *}$ \\
\hline & $(0.232)$ & $(0.125)$ \\
\hline \multirow[t]{2}{*}{ households' head marital status dummy } & -0.024 & 0.054 \\
\hline & $(0.074)$ & $(0.062)$ \\
\hline \multirow[t]{2}{*}{ households' area of residence dummy } & -0.115 & \\
\hline & $(0.153)$ & \\
\hline \multirow[t]{2}{*}{ log of the households' head level of education } & 0.069 & 0.053 \\
\hline & $(0.059)$ & $(0.037)$ \\
\hline \multirow[t]{2}{*}{ log of the households' size } & $-0.452^{* * *}$ & $-0.377^{\star * *}$ \\
\hline & $(0.047)$ & $(0.061)$ \\
\hline \multirow[t]{2}{*}{ Constant } & $11.99^{* * *}$ & $11.49^{* * *}$ \\
\hline & $(0.563)$ & $(0.557)$ \\
\hline Observations & 896 & 636 \\
\hline R-squared & 0.224 & 0.132 \\
\hline Number of HHID & 448 & 318 \\
\hline Household FE & YES & YES \\
\hline
\end{tabular}

Robust standard errors in parentheses. ${ }^{* *},{ }^{* *}$, and ${ }^{*}$ indicate significance level at $1 \%, 5 \%$ and $10 \%$ respectively.

only did we present poverty-reduction effect of infrastructure development but also its passage to the effect spanning the period from 2010 to 2013. We also address the endogeneity problem of the non-random placement of infrastructure using a reliable panel data method. We found that enhanced road infrastructure directly alleviated poverty. Infrastructure development proxied by the distance to the major roads was highly rewarding especially because of the savings from the wages of the employed households not-too-distant to the major roads which are sufficient to meet up with their consumption per capita say, during emergencies hence poverty reduced. 
We also found a seemingly interesting result on household poverty reduction effect of urban-rural movement following from infrastructure development. It indicates an increased per capita consumption for urban households. The insight is that there were over-congestion and high household poverty in the urban areas, the consequence of the available better road infrastructure in the urban areas and worse road amenities in the rural areas. However, we supposed an enormous investment in better roads in the rural areas during the periods of study which motivated urban-rural migration. Therefore, household's displacement from the urban to the rural areas was helpful in reducing urban poverty.

At the same time, we presented the effect of infrastructure development on the well-being of each household in the conflict-prone and the conflict-free settings within Nigeria. The intuition is that proximate access to the major roads and total exclusion appears to be dangerous for the well-being of each household in a conflict-prone zone unlike in the conflict-free zones. Moreover, western education should be banned to end armed-conflict issue in the North-West but under the strict condition that the perpetrators won't move to the conflict-free zones to make the same request. With that, western education violent conflict-induced could become an issue of the past not only in the conflict-prone zone but also in the country as a whole.

From the infrastructure development perspective, our study clears the ground on the issue of high poverty level in the face of high economic growth in Sub-Saharan Africa, specifically in Nigeria. In short, it supports the fact that economic growth has not translated into poverty reduction at the aggregate level. However, at the micro-level, our study shows that high employment opportunity creation through infrastructure development implies high poverty reduction. Hence, it is high time the Nigerian government, and its policymakers, started applying logic in dealing with the specific economic issue by putting attention on both aggregate and individual economic agents.

We suggest that high priorities be given to the development of road infrastructures to reduce poverty directly to its minimum. Evidences from countries such as Ghana and Tanzania confirmed and supported our suggestion. The infrastructure construction should be in such a way that they will provide easy access to other locations, and other facilities. From the policy point of view, more job creation as well as stopping the usual exploitation of the working class should dominate all other economic goals. Besides, the ongoing development of road's physical infrastructure specifically in term of access level is applauded and must continue. This may create direct effect in creation of new job opportunities and its potential reduction in the burden on urban infrastructure and dis-urbanization. However, the design of infrastructure development policies should be based on their effectiveness to eradicate poverty combined with the development commitment to combat insecurity, and unemployment at the household-level. A fruitful trend of study in future is a richer exploration into conflict and poverty dynamics at the micro-level. Such line of study may provide 
recommendations on poverty-conflict challenges in Africa.

\section{Disclosure Statement}

The authors declare that they have no conflict of interests. They would adjust to taste.

\section{References}

[1] World Poverty Clock (2018) https://worldpoverty.io/index.html

[2] World Economic Forum (2017) Global Risks of Highest Concern for Doing Business 2017.

[3] Federal Republic of Nigeria (2017) Economic-Recovery-Growth-Plan-2017-2020.

[4] Bello-Schünemann, J. and Porter, A. (2017) Building the Future: Infrastructure in Nigeria until 2040. Institute for Security Studies (ISS), West Africa Report.

[5] AFDB (2010) An Infrastructure Action Plan for Nigeria-Closing the Infrastructure Gap and Accelerating Economic Transformation. African Development Bank Report.

[6] Pison Housing Company (2013) Compendium-Report. PPP, Nigeria.

[7] James, D., Greg, S., Barri, M. and Francis I. (2016) KWM. Made in China? Financing Nigeria's Infrastructure. China Law Insight.

[8] ADB (2012) Nigeria Country Strategy Paper Draft Version 2012-2016. African Development Bank.

[9] Udo, U. (2016) Presidency Analyses 2017: Budget of Recovery and Growth, Channels Television. Channels Television.

[10] Seetanah, B., Rammesur, S. and Rojid, S. (2009) Does Infrastructure Alleviate Poverty in Developing Countries? International Journal of Applied Econometrics and Quantitative Studies, 9, 1-20.

[11] Ali, R., Barra, A.F., Berg, C.N., Damania, R., Nash, J.D. and Russ, J. (2015) Infrastructure in Conflictprone and Fragile Environments: Evidence from the Democratic Republic of Congo, Policy Research Working Paper 7273, World Bank Group, Washington DC. https://doi.org/10.1596/1813-9450-7273

[12] Ali, R., Barra, A.F., Berg, C.N., Damania, R., Nash, J.D. and Russ, J. (2015) Transport Infrastructure and Welfare: An Application to Nigeria. Policy Research Working Paper 7271, World Bank Group, Washington DC.

https://doi.org/10.1596/1813-9450-7271

[13] Pouliquen, L. (2000) Infrasturcture and Poverty. http://siteresources.worldbank.org/INTPOVERTY/Resources/WDR/Background/p ouliquen.pdf

[14] World Economic Forum and Schwab, K. (2010) The Global Competitiveness Reports.

[15] Gachassin, M., Najman, B. and Raballand, G. (2010) Roads Impact on Poverty Reduction-A Cameroon Case Study. World Bank Policy Research Working Paper, 5209.

[16] Khandker, S.R., Bakht, Z. and Koolwal, G.B. (2009) The Poverty Impact of Rural Roads: Evidence from Bangladesh. Economic Development and Cultural Change, 57, 685-722. https://doi.org/10.1086/598765

[17] Walle, V.D. and Mu, R. (2007) Rural Roads and Poor Area Development in Viet- 
nam. Social Science Research Network, Rochester, NY.

[18] Ali, I. and Pernia, E.M. (2003) Infrastructure and Poverty Reduction-What Is the Connection? ERD Policy Brief No. 13, Economics and Research Department, Asian Development Bank, Malina, Philippines.

[19] Howe, J. (2001) Assessing the Impact of Transport Infrastructure on Poverty Reduction. RETA 5947 Interim (Stage 1) Report.

[20] Ogun, T.P. (2010) Infrastructure and Poverty Reduction: Implications for Urban Development in Nigeria. WIDER, Helsinki.

https://doi.org/10.1007/s12132-010-9091-8

[21] Runsinarith, P. (2009) Infrastructure Development and Poverty Reduction: Evidence from Cambodias Border Provinces. Graduate School of International Studies, Nagoya University, Nagoya, Japan.

[22] Fan, S., Nyange, D. and Rao, N. (2005) Public Investment and Poverty Reduction in Tanzania: Evidence from Household Survey Data. DSGD Discussion Paper No. 18. International Food Policy Research Institute (IFPRI), Washington DC.

[23] Dercon, S., Gilligan, D.O., Hoddinott, J. and Woldehanna T. (2009) The Impact of Agricultural Extension and Roads on Poverty and Consumption Growth in Fifteen Ethiopian Villages. American Journal of Agricultural Economics, 91, 1007-1021. https://doi.org/10.1111/j.1467-8276.2009.01325.x

[24] Carlos, G., Cantó, O., Del Río, C. and Sarabia, J.M. (2004) Inequality, Poverty and Mobility: Choosing Income or Consumption as Welfare Indicators. Instituto de Estudios Fiscales, Madrid, Spain.

[25] Kongens, L. (2008) General Study of the Impact of Rural Roads in Nicaragua. COWI A/S Reports, Kongens Lyngby, Denmark.

[26] Tschirley, D., Walker, T., Pequenino, T., Boughton, M. Payongayong, D. and Weber, M. (2004) Determinants of Rural Income, Poverty, and Perceived Well-Being in Mozambique in 2001-2002. Michigan State University Research Paper, East Lansing, MI.

[27] Johnston, J. (1997) Econometric Methods. 4th Edition, McGraw-Hill, New York.

[28] Kennedy, P. (2008) A Guide to Econometrics. 6th Edition, Blackwell Publishers, Malden, MA.

[29] Richard, W. (2015) Panel Data: Very Brief Overview. https://www3.nd.edu/ rwilliam/stats2/Panel.pdf

[30] Allison, P.D. (2009) Fixed Effects Regression Models. Volume 160, SAGE Publications, New York. https://doi.org/10.4135/9781412993869

[31] Kemp, G. and Santos, S.J. (2016) Partial Effects in Fixed-Effects Models. United Kingdom Stata Users' Group Meetings 2016. Stata Users Group.

[32] Van de Walle, D. (2008) Impact Evaluation of Rural Road Projects. Journal of Development Effectiveness, 1, 15-36. https://doi.org/10.1080/19439340902727701 